Volume 1

Number 1 Water Law Edition

Article 6

2013

\title{
The Potential Impact of Federal Laws On State Water Supplies
}

Brad B. Castleberry

Lloyd Gosselink

Sara R. Thornton

Lloyd Gosselink

Follow this and additional works at: https://scholarship.law.tamu.edu/journal-of-property-law

Part of the Water Law Commons

\section{Recommended Citation}

Brad B. Castleberry \& Sara R. Thornton, The Potential Impact of Federal Laws On State Water Supplies, 1 Tex. A\&M J. Real Prop. L. 99 (2013).

Available at: https://doi.org/10.37419/JPL.V1.I1.6

This Symposia Article is brought to you for free and open access by Texas A\&M Law Scholarship. It has been accepted for inclusion in Texas A\&M Journal of Property Law by an authorized editor of Texas A\&M Law Scholarship. For more information, please contact aretteen@law.tamu.edu. 


\title{
THE POTENTIAL IMPACT OF FEDERAL LAWS ON STATE WATER SUPPLIES
}

\author{
By Brad B. Castleberry \& Sara R. Thornton ${ }^{\dagger}$
}

I. Introduction................................ 99

II. Water Supplies for Growing Populations......... 99

III. Section 404(c) of the Clean Water Act .......... 100

IV. Endangered Species Act ...................... 103

V. LACEY ACT ...................................... 104

VI. WiLd \& SCENIC Rivers Act ..................... 107

VII. National Wildlife Refuge System

Administration Act .......................... 109

VIII. Preventing the Invisible Legal Dam: Path

Forward for Developing Water Supplies .........

\section{INTRODUCTION}

States have long held the exclusive right to allocate their surface and groundwater supplies absent some express federal authority, usually via a contract with a federal agency for stored water in a federally sponsored and funded project. Over time, however, an emphasis on federal involvement has led to scrutiny of projects where there are no federal dollars being expended-only federal permits needed to implement projects by the states. This federal involvement can sometimes have extremely costly impacts to states, effectively creating an invisible dam of laws and regulations under the guise of protecting the environment. This paper will explore a few of those actions that are currently being experienced in the arid southwest where new reservoirs are needed to support a growing population and a thirst for water that cannot be quenched by conservation alone.

\section{Water Supplies for Growing Populations}

Water is an invaluable resource that, for many years, people believed would exist in perpetuity. As populations grow, however, this belief is confronting the harsh reality that existing water supplies are limited, and additional water supplies must be developed. In Texas,

$\dagger$ Brad B. Castleberry is a principal with Lloyd Gosselink. He practices in the areas of water law, natural resources, environmental permitting, and construction litigation. He represents clients on a variety of issues, including water supply planning, water quality management, and environmental defense. Sara R. Thornton is an associate with Lloyd Gosselink and practices in the areas of environmental, water and administrative law. She assists clients with various permitting, compliance, and enforcement issues related to water supply and water quality matters. Brad and Sara represent water purveyors throughout Texas, not only in regulatory permitting, compliance and enforcement, but also in addressing critical environmental and natural resource policy issues.

DOI: https://doi.org/10.37419/JPL.V1.I1.6 
this reality hit hard in 2011 when drought conditions reached an extreme state, requiring the Governor of Texas to declare an ongoing state of emergency due to extreme drought conditions. ${ }^{1}$ During that year, twenty-three public water systems in Texas claimed to have less than six months' water supply with the town of Spicewood Beach near Austin, Texas completely running out of water and requiring that water be trucked in for a continual water supply. ${ }^{2}$ It seems an unfathomable situation - but it's not entirely surprising when you understand how population has grown in Texas, whereas Texas' water supply storage has not. ${ }^{3}$ In fact, since 1980 , the per capita water storage in Texas has decreased by $30 \%{ }^{4}$

According to the Water for Texas 2012 State Water Plan, Texas is the second most populated state in the U.S. and it had a greater population growth than any other state between 2000 and 2010-increasing from 20.8 million to 25.1 million. $^{5}$ This growing population is not expected to slow, but instead, between 2010 to 2060 it is expected to grow approximately $80 \%$ to 46.3 million. ${ }^{6}$ Thankfully, this estimated growth does not have a corresponding percentage increase in demand for water-instead, the water demand is only projected to increase by $22 \%$, given the implementation of conservation and reuse. ${ }^{7}$ Even so, based on the current inability to meet existing water demands under newly experienced drought conditions, additional water supplies must be developed to also meet this increased demand. But to accomplish this, additional water supply projects will have to find a way to overcome a myriad of invisible "dams" that may be created by certain federal laws and regulations, potentially blocking development.

\section{Section 404(c) of the Clean Water Act}

The development of additional water resources, including new water supply reservoirs, must comply with a number of federal laws, including Section 404 of the Clean Water Act ("CWA"). Pursuant to Section 404 of the CWA, the U.S. Army Corps of Engineers ("USACE") may issue a permit ("404 permit") for the discharge of dredged or fill material into the navigable waters at specified disposal

1. Office of the Tex. Gov., Proclamation, Perry Again Renews Proclamation Extending Drought Emergency (Dec. 28, 2012), http://governor.state.tx.us/news/procla mation/18013/.

2. Marc Airhart, Five Key Lessons (and Challenges) from the Great Texas Drought, KNow (Sept. 10, 2012), http://www.utexas.edu/know/2012/09/10/great-texasdrought.

3. Id.

4. Id.

5. Water for Texas 2012 State Water Plan 129, Tex. Water Dev. Bd. (2012), http://www.twdb.state.tx.us/publications/state_water_plan/2012/03.pdf.

6. Id. at 132 .

7. Id. at 136 . 
sites after notice and opportunity for a public hearing. ${ }^{8}$ Importantly, without a 404 permit, a new water supply reservoir cannot be constructed given the necessity of the actions involved in construction. Beyond complying with the numerous requirements for a 404 permit to be issued, a permittee is also faced with the possibility that the permit issuance by the USACE may be vetoed by the Environmental Protection Agency ("EPA")—effectively killing the water supply reservoir.

Under Section 404(c) of the CWA, the EPA is expressly given the right to veto a 404 permit application either before or after the USACE's approval of such application. ${ }^{9}$ Section 404 (c) provides that the Administrator of the EPA may outright prohibit the issuance of a 404 permit or overrule the USACE determination to issue a permit by "withdrawal of specification." 10 The Administrator may veto a 404 permit after notice and opportunity for public hearing and when he or she determines that issuing the 404 permit will have an unacceptable adverse effect on (1) municipal water supplies, (2) fish and wildlife, or (3) recreational areas. ${ }^{11}$ The Administrator may only make this determination after consulting with the Secretary of the Army, acting through the Chief of Engineers, and then the Administrator must set forth in writing and make public the reasons for prohibiting the 404 permit. $^{12}$

As of 2013, the EPA has vetoed thirteen 404 permits pursuant to Section 404 (c) of the CWA. ${ }^{13}$ The types of projects vetoed vary, but most were vetoed due to unacceptable adverse impacts to a variety of aquatic resources and wildlife habitats. Four of the projects vetoed were reservoir projects-(1) Two Forks Reservoir, final determination in 1990; (2) Big River, final determination in 1990; (3) Ware Creek, final determination in 1989; and (4) Lake Alma, final determination in $1988 .{ }^{14}$

Although the EPA has not vetoed a water supply reservoir since 1990, the EPA's veto authority under Section 404(c) is alive and well-and the extent of that authority is currently being tested in the courts. On January 13, 2011, the EPA issued a Final Determination to withdraw specification of certain streams as disposal sites for dredged

8. Clean Water Act of $1977 \S 404(a), 33$ U.S.C. $\S 1344(a)$ (2006).

9. Id. § 1344(c); see also 40 C.F.R. § 231.1(a) (2011).

10. Id.; 40 C.F.R. $\$ 231.2$ (a) (2011) (quoting "Withdraw specification means to remove from designation any area already specified as a disposal site by the U.S. Army Corps of Engineers or by a state which has assumed the section 404 program, or any portion of such area.").

11. $\S 1344(\mathrm{c})$.

12. Id. § 1344(c)-(d).

13. See generally Chronology of 404(c) Actions, U.S. Envtl. Prot. Agency, available at $\mathrm{http}: / /$ water.epa.gov/lawsregs/guidance/wetlands/404c.cfm (last updated Aug. 21, 2012).

14. Id. 
or fill material in connection with the construction of a surface mineessentially vetoing certain portions of an existing 404 permit authorizing such disposal sites that was issued by the USACE almost three years before EPA's veto. ${ }^{15}$ The basis of EPA's veto was that the discharge of dredged or fill material associated with the construction and operation of the coal mine would result in unacceptable adverse effects on wildlife, particularly through significant loss of wildlife habitat and significant degradation of downstream aquatic ecosystems. ${ }^{16}$ The coal mine operator filed suit against EPA seeking a declaration that EPA lacked the authority to modify or revoke the 404 permit following the USACE's issuance of the permit. ${ }^{17}$ The district court agreed with the coal mine operator, holding that EPA lacked the authority under section 404(c) to utilize its veto authority for an indefinite period of time after the permit has been issued. ${ }^{18}$ But EPA has appealed this decision, which is currently before the U.S. Court of Appeals for the D.C. Circuit.

EPA's veto of a 404 permit for a reservoir is not outside the realm of possibility if it determines that a reservoir would have unacceptable adverse impacts to aquatic resources and wildlife habitat. In the most recent veto of a 404 permit for a water supply reservoir, the Two Forks Reservoir in 1990, EPA based its veto on a number of factors. EPA determined that the project would have significant impacts to fisheries, by eliminating trout habitat that would in turn reduce trout standing crop. ${ }^{19}$ EPA also noted impacts to endangered species, including the bald eagle and peregrine falcon, along with impacts to other wildlife. ${ }^{20}$ Another basis for EPA's veto was the lack of a need for the water supply project, particularly that there was no need within the next twenty-five years for the water supply. Further, the population the project would serve was actually decreasing, which was in turn expected to result in a decrease in demand for water supplies. ${ }^{21}$

The lack of a recent veto action of a large reservoir project may be due in part to a lull in the construction of dams and reservoirs across the United States. But, with the increasing need for additional water supplies, new water supply reservoirs must be developed. In fact, the Texas 2012 State Water Plan identifies a number of new reservoirs to meet water demands throughout the state that will require 404 permits and must survive EPA scrutiny and its veto. EPA's prior veto

15. Mingo Logan Coal Co. v. EPA, 850 F.Supp.2d 133, 136-37 (D.D.C. 2012), appeal docketed, No. 12-5150 (D.C. Cir. filed May 15, 2012).

16. Final Determination Notice of The Clean Water Act Concerning The Spruce No. 1 Mine, 76 Fed. Reg. 3126 (Jan. 19, 2011).

17. Mingo, 850 F.Supp. at 134.

18. Id. at 153 .

19. Proposed Determination South Platte River, 54 Fed. Reg. 36,862, 36,866 (Sept. $5,1989)$.

20. Id.

21. Id. 
actions, and the bases for each, should be used by those developing water supplies as a precautionary guide for securing a 404 permit.

\section{Endangered Species Act}

The Endangered Species Act ("ESA"), believed to be perhaps the most stringent, comprehensive, and controversial environmental legislation in the history of the United States, also poses a significant barrier to the development of additional water supplies in Texas. ${ }^{22}$ Enacted in 1973, the ESA provides protection to endangered and threatened species and their habitats by prohibiting the "take" of listed species and any interstate or international trade of listed species. $^{23}$ Under Section 7 of the ESA, federal agencies are required to "insure that any action authorized, funded, or carried out by such agency . . . is not likely to jeopardize the continued existence of any endangered species or threatened species or result in destruction or modification of habitat of such species which is determined by the Secretary [of the Interior] . . . to be critical."24 Critical habitat must be designated for listed species under the ESA when it is deemed "prudent and determinable" and includes geographic areas containing the physical or biological features essential to the conservation of the species and potentially needing management and protection. ${ }^{25}$ Only federal agency actions or federally funded or permitted activities must avoid impacts to critical habitat. ${ }^{26}$

The USACE's issuance of a 404 permit for a water supply project qualifies as an agency action that must comply with section 7 of the ESA. If the project might affect threatened or endangered species or their designated critical habitat, the USACE must consult with the United States Fish \& Wildlife Service ("FWS") or the National Marine Fisheries Service ("NMFS"), as applicable, before deciding whether to issue the permit. Additionally, the 404 permit applicant would need to submit a biological evaluation for the species as part of its 404 permit application. The existence of a listed species, or its critical habitat, within the area of a water supply project could significantly impede and slow the development of the project. In Texas, a number of species are currently being proposed for listing as endangered or threatened, known as "candidate" species, or currently petitioned for listing. Of these species, twelve are freshwater mussels found throughout the state in multiple river basins. ${ }^{27}$ There is no

22. Endangered Species Act Law, Policy and Perspectives 1 (Donald C. Baur \& Wm. Robert Irvin eds., 2d ed. 2010).

23. Id

24. 16 U.S.C. $\$ 1536(\mathrm{a})(2)(2000)$.

25. 16 U.S.C. $\S 1533(\mathrm{a})(3)(2000) ; 16$ U.S.C. $\$ 1532(5)(A)(2000)$.

26. Baur \& Irvin, supra note 22 , at $45-46$.

27. Federal Status of the Texas Mussels listed by the State of Texas, U.S. FisH \& WILDLIFE SERv. (Oct. 2011), http://www.fws.gov/southwest/es/Documents/R2ES/Status_Table_Texas_Mussels_Oct_2011.pdf. 
doubt that the listing of these mussel species, and designation of critical habitat for same, would impact the development of future water supplies in Texas.

An applicant for a 404 permit can take certain proactive measures to ensure compliance with the ESA in anticipation of a listing which might occur within a water supply project footprint. For instance, an applicant may seek to enter a Candidate Conservation Agreement with Assurances with the FWS pursuant to section 10 of the ESA. ${ }^{28}$ The applicant might enter into such an agreement with the FWS and agree to certain voluntary conservation measures, and in exchange may receive a permit from the FWS that provides assurance that additional land, water, or resource use restrictions under the ESA will not be imposed on the applicant in the event the species becomes listed in the future. ${ }^{29}$

\section{LACEy ACT}

An additional federal law, not widely known for affecting the development of reservoirs and other future and existing water supplies, is the Lacey Act. The federal government originally enacted the Lacey Act in 1900 to outlaw the interstate trafficking of birds and other animals illegally killed in their state of origin. ${ }^{30}$ But, in the wake of invasive species like the zebra mussel, Asian carp, and snakehead fish, which are spreading across the United States at an unprecedented rate, the Lacey Act was amended to also address these foreign invaders. Section 42 of the Lacey Act prohibits the importation, shipment or possession of injurious mammals, birds, fish (including mollusks and crustacea), amphibia, and reptiles. ${ }^{31}$ Zebra mussels are one of a few species specifically prohibited within section 42 , whereas other injurious species, injurious to human beings, to the interests of agriculture, horticulture, forestry, or to wildlife or to the wildlife resources of the United States, are identified by the Secretary of the Interior and included in Part 16 of Title 50 of the CFR. ${ }^{32}$ The purpose of 50 CFR Part 16 is to implement the Lacey Act. ${ }^{33}$

Section 16.13 of 50 CFR provides that " $\mathrm{t}]$ he importation, transportation, or acquisition . . of live mollusks, veligers, or viable eggs of zebra mussels, genus Dreissena" is prohibited. ${ }^{34}$ Section 42 of the

28. Using Existing Tools to Expand Cooperative Conservation for Candidate Species Across Federal and Non-Federal Lands 1, U.S. Fish \& Wildlife SERV., http:// www.fws.gov/endangered/esa-library/pdf/CCA-CCAA $\% 20 \% 20$ final $\% 20$ guidance $\%$ 20signed \%208Sept08.PDF.

29. Id.

30. Lacey Act, U.S. FISH \& WILdLIFE SerV., http://www.fws.gov/international/ laws-treaties-agreements/us-conservation-laws/lacey-act.html.

31. Lacey Act $\S 42,18$ U.S.C. $\S 42(a)(1)$ (Supp. V 2012).

32. Id.; see also 50 C.F.R. $\$ 16.1-16.33$ (2012).

33. 50 C.F.R. $\S 16.1$.

34. 50 C.F.R. $\S 16.13(\mathrm{a})(2)(\mathrm{iii})$. 
Lacey Act and Part 16 of 50 CFR apply to the importation of injurious species, e.g., zebra mussels, into the United States or the transportation between the continental United States, the District of Columbia, Hawaii, the Commonwealth of Puerto Rico or any territory or possession of the United States by any means without a permit issued by the FWS. ${ }^{35}$ Therefore, a violation of section 42 of the Lacey Act could only occur if an invasive species like the zebra mussel is transported across state lines. Most would think this provision was intended to prevent people from intentionally smuggling invasive species-but this provision, by its plain language, applies to any interstate transport regardless of the intent or the mechanism of transport. This means any water supply project that moves water containing invasive species across state lines results in a violation of section 42 of the Lacey Act.

The Great Lakes, no stranger to invasive species, is subject to a new threat-the introduction of bighead and silver carp, types of Asian carp. This potential invasion is likely to occur through the Chicago Area Waterway System ("CAWS"), a man-made connection between the Mississippi River Basin and Lake Michigan. ${ }^{36}$ This invasion via this man-made connection could also result in Lacey Act violations. ${ }^{37}$

Five states bordering the Great Lakes filed suit against the USACE and the Metropolitan Water Reclamation District of Greater Chicago ("Metro District"), the entities operating CAWS, seeking injunctive relief requiring USACE and Metro District to take all measures to prevent the spread of Asian carp into Lake Michigan because failure to do so would create a public nuisance. ${ }^{38}$ The states' request for injunctive relief was denied. ${ }^{39}$ In December 2012, the court dismissed the states' claims of public nuisance and violations of the Administrative Procedure Act because operation and maintenance of CAWS by USACE, and not closing CAWS, is mandated by federal law. ${ }^{40} \mathrm{Ab}-$ sent a constitutional violation, the court could not order "parties to take action that would directly contravene statutory mandates and prohibitions, and the common law recognizes that actions required by law do not give rise to liability for nuisance." 41 But this does raise a question as to when and if Asian carp invade Lake Michigan, will the FWS proceed against the USACE and Metro District for violations of

35. Injurious Wildlife: A Summary of the Injurious Provisions of the Lacey Act (18 U.S.C. 42; 50 CFR 16), U.S. FISH \& Wildlife SERV., http://www.anstaskforce. gov/Documents/Injurious_Wildlife_Fact_Sheet_2007.pdf (emphasis added).

36. Michigan v. U.S. Army Corps of Eng'rs, No. 10C4457, 2012 WL 6016926, at *1 (N.D. Ill. Dec. 3, 2012).

37. Id. at 20-21.

38. Michigan v. U.S. Army Corps of Eng'rs, No. 10-CV-4457, 2010 WL 5018559, at

*1 (N.D. Ill. Dec. 2, 2010), aff'd, 667 F.3d 765 (7th Cir. 2011).

39. Id.

40. Michigan, 2012 WL 6016926, at *1.

41. Id. 
the Lacey Act? Even the court recognized that a Lacey Act violation could occur, but apparently no action by FWS has been taken-yet. ${ }^{42}$

Violations of the Lacey Act are not restricted to areas like the Great Lakes. In fact, two water supply projects in North Texas recently faced this very issue - that through the simple act of operating a pump station the projects could be subject to fines of up to $\$ 500,000$ for a violation of section 42 of the Lacey Act. ${ }^{43}$ In early 2009, the Texas Parks and Wildlife Department discovered zebra mussels in Lake Texoma, a reservoir located on the boundary of Oklahoma and Texas. ${ }^{44}$ The zebra mussels were presumably introduced into Lake Texoma by boaters from northern states. Zebra mussels spread via overland dispersal-by attaching to boats and surviving out of water for up to several days before the boat is placed back into water and then spreading throughout the new body of water. ${ }^{45}$

One of the water supply projects, owned and operated by the North Texas Municipal Water District ("NTMWD"), diverted water from Lake Texoma within Oklahoma that was then transported to and through Lake Lavon, a lake wholly in Texas. NTMWD, upon learning of the introduction of zebra mussels into Lake Texoma, ceased diversions from the lake to prevent the spread of zebra mussels into Texas. Had it not done so, NTMWD could have faced significant charges for civil and criminal violations under the Lacey Act because diverting water from Lake Texoma would have resulted in an interstate transport of invasive species. But, ongoing drought conditions and increasing water demands necessitated that NTMWD ultimately access its Lake Texoma water supplies, which constitute $25 \%$ of its total water portfolio. To achieve this, NTMWD decided to expend significant resources to construct an approximately 48-mile pipeline to transport the Lake Texoma water directly to a water treatment plant where all zebra mussels would be extirpated-preventing further introduction or propagation of zebra mussels into Texas's waterways. Additionally, NTMWD had to secure federal legislation for an exemption from the Lacey Act for this conveyance because it still constitutes a violation of the Lacey Act even though no zebra mussels would actually be introduced and transported into other bodies of water in Texas. ${ }^{46}$

Although it seems that this situation is unique, the potential for future applications of the Lacey Act restricting water supplies is not at all unlikely. Multiple reservoirs are located on boundaries of states that are defined by rivers, particularly in Texas. As more freshwater

42. $I d$. at $20-21$.

43. See 18 U.S.C. $\S 3571$ (c) (2006).

44. Lone Zebra Mussel found in Lake Texoma, Tex. PARKs \& Wildlife, TPWD (Apr. 29, 2009), http://www.tpwd.state.tx.us/newsmedia/releases/?req=20090421a.

45. Id.

46. Lake Pontchartrain Basin Restoration Program, Pub. L. No. 112-237, § 5, 126 Stat. 1628, 1629 (2012). 
invasive species are introduced and designated, moving these species across state lines will be subject to the Lacey Act - with the potential to completely cut off such water supply without obtaining a legislative exemption from the Lacey Act—not so easy to obtain.

\section{WiLd \& Scenic Rivers Act}

As the need to develop additional water supplies grows, others will seek to preserve these waters, particularly rivers, in their natural state to prevent their development for use as water supplies. One mechanism for doing so is through the designation of a river pursuant to the National Wild \& Scenic Rivers Act ("WSRA"). Congress passed the WSRA in 1968 for the purpose of declaring that selected rivers be preserved in a free-flowing condition and their immediate environments be protected. ${ }^{47}$ Under the WSRA, "free-flowing" means "existing or flowing in natural condition without impoundment, diversion, straightening, rip-rapping, or other modification of the waterway." 48 Rivers are selected for inclusion in the WSRA based on their outstandingly remarkable values, which includes, but is not limited to, scenic, recreational, geologic, fish and wildlife, historic, and cultural values. ${ }^{49}$ A river may be included in the National Wild and Scenic Rivers System ("National System") either by an act of Congress or through designation by the Secretary of the Interior following protection in a state river system and application by the state governor. ${ }^{50}$

In a perfect world, preserving all rivers in their free-flowing state would be ideal. But, we do not live in a perfect world-we live in a world with an ever-expanding population that cannot survive on existing freshwater supplies. This is particularly true in Texas. The designation of a river as wild and scenic could effectively eliminate that river as a future water supply. Designation of a river requires the federal government to protect the river's instream flow, which it may do through the reservation of federal water rights. ${ }^{51}$ Under the WSRA, the quantity of water for a federal water right is only the amount necessary to achieve its purposes, meaning that the federal government can only acquire the rights to preserve the outstanding remarkable values for which the river was protected. ${ }^{52}$ Further, the U.S. Supreme Court has held that the federal government may only reserve "unappropriated" water. ${ }^{53}$ The priority date of the federal reserved right would likely date back to the date of the river's designation, but the

47. 16 U.S.C. $\S 1271(2000)$.

48. 16 U.S.C. $\$ 1286($ b) (2000).

49. 16 U.S.C. $\$ 1271$.

50. 16 U.S.C. $\$ 1273($ a) (2000).

51. Nat'l Wild \& Scenic Rivers Sys., Water Quantity and Quality as ReLated to the Management of Wild \& Scenic Rivers 1 (Oct. 2003).

52. 114 Cong. Rec. 26,594 (1968).

53. See generally Cappaert v. United States, 426 U.S. 128 (1976); see also United States v. New Mexico, 438 U.S. 696 (1973). 
legislation designating the river may specify some other date of priority. ${ }^{54}$ The federal right would be junior to rights existing on the date of the establishment of the federal right but senior to all rights vesting after that date. ${ }^{55}$

The potential for federal water rights causes serious concern for state and local governments whose water use and future water diversions may be impacted by new downstream wild and scenic segments. ${ }^{56}$ For instance, suppose the designated portion of the river is located downstream of a diversion point for a water right holder. ${ }^{57}$ If the holder's rights are junior to the federal government's appropriation, then the federal government can place a "call" on the river. ${ }^{58}$ This means the federal government can demand the upstream junior appropriators, including the water right holder, withhold their beneficial use and provide sufficient water to meet the federal government's water right under the WSRA. And in the reverse, if the water rights holder's rights are more senior to the federal government's appropriation, their use would have priority over the federal government. ${ }^{59}$

But, having a senior water right may not protect public or private parties either because the WSRA appears to allow the federal government to "take" water rights. ${ }^{60}$ The federal government may have to pay for those rights, ${ }^{61}$ but money alone cannot replace existing freshwater supplies. The WSRA seems to give the federal government the ability to condemn other water rights: "any taking by the United States of a water right which is vested under either State or Federal law at the time such river is included ... shall entitle the owner . . . to just compensation." 62

The WSRA also prohibits federally assisted water resources projects if they would have a "direct and adverse effect" on the values for which a river was added to the National System. ${ }^{63}$ Such water

54. See Winters v. United States, 207 U.S. 564, 577 (1908) (stating priority date for water rights reserved for Indian Tribes was held to be the date of the Treaty reserving such rights).

55. Cynthia Brougher, Cong. Research. Serv., Rl41081, The Wild and Scenic Rivers Act and Federal Water Rights 5 (2010), http://www.rivers.gov/ publications/crs-water-rights-2010.pdf.

56. Sharon Megdal et al., The Forgotten Sector: Arizona Water Law and the Environment, 1 Ariz J. EnvtL. L. \& POL'y 243, 259 (2011).

57. Joseph L. Sax, Barton H. Thompson, Jr., John D. Leshy \& Robert H. Abrams, Legal Control of Water Resources: Cases and Materials 671 (4th ed. 2006).

58. Megdal et al., supra note 56, at 259.

59. Id.

60. Id.

61. Id.

62. 16 U.S.C. $\S 1284(b)$ (Supp. V 2012).

63. Nat'l Wild \& Scenic Rivers Sys., Wild and Scenic Rivers Act: Section 7, 5-6 (2004), http://www.rivers.gov/rivers/documents/section-7.pdf. The Act also specifically prohibits the Federal Energy Regulatory Commission from licensing the construction of any dam, water conduit, reservoir, powerhouse, transmission line, or 
resources projects that would likely be subject to this standard include, but are not limited to:

dams; water diversion projects; fisheries habitat and watershed restoration/ enhancement projects; bridge and other roadway construction/reconstruction projects; bank stabilization projects; channelization projects; levee construction; recreation facilities such as boat ramps and fishing piers; and, activities that require a Section 404 permit from the [USACE]. ${ }^{64}$

This prohibition also applies to rivers designated for potential addition in the National System until such time as the river is either designated or determined to not be included in the National System. ${ }^{65}$ So, if a river is designated or proposed for designation, there is little chance that the river may be developed in the future as a potential water supply project. Even projects upstream or downstream of the river may be affected, since such projects will only be allowed if the designated river is not invaded by the project, or the scenic, recreational, fish, or wildlife values present at the date of designation are not unreasonably diminished. ${ }^{66}$ Consequently, every effort must be made to ensure that Texas rivers identified as potential or existing sources of water supplies do not become designated in a way that would prevent their use as a water supply.

\section{ViI. National Wildlife Refuge System Administration Act}

The National Wildlife Refuge System Administration Act ("NWRSA"), much like the WSRA, can also effectively block the development of water supplies. Originally enacted in 1966, NWRSA is the "organic act" for the National Wildlife Refuge System (the "Refuge System") and sets forth all the guidelines and directives for the administration and management of all areas in the system. ${ }^{67}$ The Refuge System consists of "wildlife refuges, areas for the protection and conservation of fish and wildlife that are threatened with extinction, wildlife ranges, game ranges, wildlife management areas, [and] waterfowl production areas." ${ }^{8}$ In 1997, Congress amended NWRSA to manage the Refuge System as a national system of related lands, waters, and interests for the protection and conservation of the nation's wildlife resources. ${ }^{69}$ Once any area is designated as part of the Refuge

other project works under the Federal Power Act on or directly affecting any river in the National System. 16 U.S.C. $\$ 1278($ a).

64. Id. at 6 .

65. 16 U.S.C. $\$ 1278$ (b)-(b)(i) (2000).

66. Wild AND SCEnic Rivers ACt: SECTION 7, supra note 63, at 6.

67. U.S. Fish \& Wildlife Serv., Digest of Federal Resource Laws of Interest to the U.S. Fish and Wildlife Service, National Wildlife Refuge SYSTEM Administration ACt, available at http://www.fws.gov/laws/lawsdigest/ NWRSACT.HTML.

68. 16 U.S.C. $\$ 668 \mathrm{dd}(\mathrm{a})(1)(2000)$.

69. U.S. Fish \& WildLIFE SERV., supra note 67. 
System, "no person shall disturb, injure, burn, remove, destroy or possess any real or personal property of the United States, including natural growth, in any area of the System."70

Not surprisingly, the location of a water supply reservoir within an area of the Refuge System is also prohibited, which is precisely what happened to the Fastrill Reservoir. The Fastrill Reservoir was originally identified as a potential reservoir to serve the Dallas/Ft. Worth Metroplex in 1961 at a site along the Upper Neches River in Texas. ${ }^{71}$ The reservoir was subsequently included and incorporated in state water planning beginning in 1984, and subsequently in regional water plans in 1997, 2001, and 2005. ${ }^{72}$ In 1985, the USFWS identified the site of the Fastrill Reservoir as a potential wildlife refuge. ${ }^{73}$ Due to funding constraints, the USFWS conducted only a draft environmental assessment ("EA") of the site as a wildlife refuge in 1988 and the project was set aside. ${ }^{74}$

Not until 2003 did the USFWS revive the process for examining designation of the site of the Fastrill Reservoir as a wildlife refuge. ${ }^{75}$ From 2003 to 2005, the UFWS gathered public input regarding the designation of the refuge, prepared another EA, and determined that an environmental impact statement ("EIS") did not need to be prepared. ${ }^{76}$ During this time, the City of Dallas and the State of Texas continued to identify the Fastrill Reservoir as a potential reservoir site in the state and regional water plans, and, in 2005, the Texas legislature designated the Fastrill Reservoir as a "critical resource."77 Then, on August 23, 2006, a landowner, in the footprint of the reservoir site and proposed acquisition boundary of the refuge, granted USFWS a conservation easement on a one-acre tract of land-thereby creating the Neches Wildlife Refuge. ${ }^{78}$ Dallas and Texas filed instant suits claiming that the EA was flawed, that an EIS should have been prepared, and that the refuge violated the 10th Amendment. ${ }^{79}$ The district court ruled in favor of the USFWS and its designation of the refuge, and Dallas and Texas appealed. ${ }^{80}$

On appeal, the court determined that the EA conducted by the USFWS was sufficient, the USFWS's decision-making process was not arbitrary and capricious, an EIS was not required, and did not con-

70. 16 U.S.C. $\S 668 \mathrm{dd}(\mathrm{c})(2000)$.

71. City of Dallas v. Hall, 562 F.3d 712, 715 (5th Cir. 2009).

72. $I d$.

73. $I d$.

74. Id. at 716 .

75. $I d$.

76. Id.

77. Id.

78. Id.

79. Id.

80. Id. 
sider the 10th Amendment argument. ${ }^{81}$ The court's decision turned in part on the fact that only preliminary proposals and studies had been conducted by Dallas and Texas on the reservoir; therefore, the USFWS had little ability, or requirement, to assess potential impacts regarding the Fastrill Reservoir. ${ }^{82}$ The ultimate effect of this decision is that the Fastrill Reservoir is effectively blocked from development. Further, it appears that even when a state plans for water supplies, those plans may be for naught if state and federal permits and property have yet to be acquired for the project.

\section{ViII. Preventing the Invisible Legal Dam: Path Forward for Developing Water Supplies}

With the invisible "dam" these myriad of federal laws could create, the development of needed water supplies must be undertaken with careful planning and preparation, particularly in establishing the need for the water supply project and selecting (1) the source of supply; (2) the type of water supply project; and (3) the location of such water supply project. It is imperative to understand the interplay between federal laws and water supply project development even if there are no federal resources to be expended in constructing or operating the project. The permitting process alone can be a minefield based upon the laws discussed herein, along with others, including the National Environmental Policy Act, the National Wildlife Refuge System Administration Act, and section 402 of the Clean Water Act. As Texas, and the arid but growing southwest, continue to grapple with growing populations, water supply projects will be needed and states will have to understand their ability to timely develop resources in cooperation with the federal government.

81. Id. at $718-23$.

82. Id. at 719 . 
